\title{
Psychological conditions in caregivers of the elderly with dementia: brazilian cases
}

\begin{abstract}
Introduction: the aging of the population is a reflection of medical and scientific advances. Studies have turned their attention to the population of caregivers considering the possibilities of stress and depression from this condition, facts that can have impacts on the caregiver-elderly dyad. Objective: to identify the emotional, behavioral and adaptive aspects of family caregivers of the elderly with Major Neurocognitive Disorder (MND). Method: sample comprised of 54 family caregivers of elderly people with Major Neurocognitive Disorder (MND) attended at three services for the elderly, from Baixada Santista (SP)/Brazil, using the Self Assessment Questionnaire for Adults aged 18 to 59 years (Adult Self-Report-ASR). The data were treated descriptively by the variables: sex and time of care. Results: a tendency to internalizing (emotional) problems was found in women and those who cared for the elderly for up to one year had more adaptive means than those who took one to three years. Final considerations: The results indicate the presence of emotional impacts, vulnerability and stress from the caring activity in caregivers of the elderly with MND.
\end{abstract}

Keywords: aging, caregivers, psychological problems
Volume 3 Issue 2 - 2018

\author{
Janice Ventura Silva Ribeiro, Márcia Maria \\ Pires Camargo Novelli, Nancy Ramacciotti \\ de Oliveira-Monteiro \\ 'Master's degree from the Interdisciplinary Program in Health \\ Sciences, Federal University of São Paulo, Brazil \\ ${ }^{2}$ Management and Health Care Department, Federal University \\ of São Paulo, Brazil \\ ${ }^{3}$ Marine Sciences Department, Federal University of São Paulo, \\ Brazil
}

Correspondence: Nancy Ramacciotti de Oliveira-Monteiro, Federal University of São Paulo, 126 Silva Jardim, Santos, São Paulo, Brazil,Tel +55 (13) 32290 I00, Email nancy.unifesp@gmail.com

Received: June 01, 2017| Published: April 16, 2018
Abbreviations: ADM, assessment data manager; ASEBA, achenbach empirically based assessment system battery; ASR, adult self report; IBGE, brazilian institute of geography and statistics;WHO, world health organization; MND, major neurocognitive disorder

\section{Introduction}

Old age is a historical process, lived differently between men and women. To understand these differences, cultural, emotional and socioeconomic factors must be taken into account. Aging can be understood as a natural process by which all people must pass. In this process the progressive reduction of the functions of the individuals (senescence), does not usually bring bigger problems. However, other adverse conditions, such as diseases, accidents and stress can cause pathological health conditions (senility) that will require assistance..$^{1,2}$

The changes in relation to human life expectancies in the first half of the 21 st century are considered the greatest epidemiological transition of all time. Caused by the medical and scientific revolution, they dramatically altered the profile of the global population, with declining mortality and birth rates. As a result, we see the phenomenon of aging of the world population and this aging brings with it other demands on health, especially on how to deal with the functional incapacity of these individuals. Functional capacity refers to the maximum competence to perform before an activity, for example, in the performance of activities of daily living and the disability reflects the difficulties that may exist in this performance. ${ }^{3}$

According to Freitas et al. ${ }^{4}$ in considering the aging process, the idea that there is only one mechanism that controls the rate of aging is very simple, as each person ages at different rates, and changes in time-related function and performance individual differences. These changes, which include: disease-related changes, constant decline in function, precipitous manifestations of illness, compensatory and cultural changes, are very important in assessing the conditions and functional capacity of an individual.
According to the World Health Organization, ${ }^{5}$ the path towards well-being requires that health systems meet the challenges and expectations of a changing world in which people live longer, compared to 30 years. On the other hand, in many countries, people face a health system that is incapable of providing care at the national level, of quality and that meets the expectations of its users. Elements of disordered urbanization and globalization have increased the number of communicable diseases and have accentuated the burden of chronic and non-communicable diseases. The large number of people who have developed complex symptoms and multiple illnesses have put service delivery in check and are challenging a more integrated case management that covers a larger number of individuals. ${ }^{5}$ It is estimated that between 2000 and 2050, the number of people over 60 will double in the world, and in 2050 more than one in five people will be over 60 . Of this population, $80 \%$ of the elderly live in low- and middle-income countries, according to the figure below.,

A National Household Sample Survey (PNAD) of 2012, carried out by $\mathrm{IBGE}^{7}$ in Brazil, pointed out that a large part of the Brazilian population (42\%) lived in the Southeast Region where the state of São Paulo is located, a federation unit that had 5.3 million people over 60 years old, the equivalent of $12.2 \%$ of the population of the country where the survey was conducted.

Still on the pathological dimensions, in the senile old age (aging with disease), the Major Neurocognitive Disorder (MND) problem stands out. There are factors that increase MND care costs, such as: 1) increased demand for care, 2) continued care, and 3) the need for the presence of a caregiver who usually leaves work to care for of the elderly, generating income loss at a critical moment, when spending increases. ${ }^{8}$

According to the DSM-V, the criteria for the diagnosis of MND are evidence of the decline of one or more areas of cognitive domain reported and documented through standardized tests that cause impairment in the individual's independence for their activities 
of daily living (ADL). The term dementia of DSM-IV can be used even in contexts where the physician and patient are accustomed to it and are incorporated into the MND, although its use in etiological subtypes is not excluded in which it is a standard term for the specific subtypes of Neurocognitive Disorders. ${ }^{9}$

Introduced in 1906 by the German psychiatrist Alois Alzheimer (1864-1915), Alzheimer's disease (AD) is the most common cause of MND, with age being the main risk factor for its development. Although there is no knowledge of why the disease occurs, the characteristics of the brain lesions associated with it are already known. These occur due to the formation of senile plaques as a consequence of the deposition of abnormally produced beta-amyloid protein, neurofibrillary tangles caused by hyperphosphorylation of the tau protein, reduction of neurons and synaptic connections, and progressive loss of brain volume. ${ }^{10}$

$\mathrm{AD}$ is in the group of the most important diseases that bring progressive functional decline, in addition to the gradual loss of independence of the elderly, resulting in their dependence on other people as the disease progresses. This decline can be observed in the deterioration of cognitive functions, with the emergence of behavioral disorders and neuropsychiatric symptoms and, from this, the person can not perform the daily activities of life. ${ }^{11}$

In the face of chronic-degenerative diseases, such as $\mathrm{AD}$, which is insidious in nature, care for the elderly is gradually more necessary, to the point of being integral to the final stages of the disease, which can totally affect the quality of life of the elderly. elderly and their family caregivers. $^{12}$

The term caregiver refers to someone who provides care to another person who, for some type of disability, needs help. ${ }^{13}$ The International Classification of Functioning, Disability and Health (CIF) classifies caregivers as individuals who provide the necessary services to assist others in their daily activities. This work can be carried out by paid people and by family members or volunteers who receive no remuneration. ${ }^{14}$

Regarding the professionalization of the activity, the occupation called 'carer of the Elderly' has been part of the Brazilian Occupational Classification (CBO) since 2002 (code 5162-10) and is recognized as an economic activity of professionals in Brazil. Such occupation is governed by the same rules as the domestic worker and permits the registration in a workbook with the name 'caregiver of the elderly', but this occupation does not cover the family caregiver, and still lacks governmental regulation and approval, since the criteria are questioned minimum required for the training of the professional caretaker. ${ }^{15,16}$

On the other hand, WHO5 advocates that 'the family is the cornerstone of care' in aging, on the understanding that the family is the primary caregiver. It is usually the family caregiver who ends up taking on this task even without being prepared. Regardless of the degree of kinship, there are many emotional implications involved in the task of caring for an elderly person with MND. From family caregivers, flexibility is required to adapt to the constant changes that occur in the life of the elderly, and these changes can bring a negative perception on the part of the caregiver as a consequence of the losses suffered during the caring process, such as: little time to take care of lack of leisure, excessive hours in care and lack of support from other family members or professionals. ${ }^{17}$
There is evidence that caring for elderly people - with impairment in their ADL and dependents - causes overload in the caregiver and in the elderly., ${ }^{418}$ In a study of 22 informal caregivers of the elderly, in the city of Formiga (MG), Rossi et al.12 sought to identify the profile of informal carers of elderly with $\mathrm{AD}$. The caregivers investigated in this study were mostly female relatives (married and aged 40 and 60 years). Other family members (spouses, children and siblings) also took care for a period of two to ten years. Because of this care, the most commonly reported feelings and conditions were anxiety, melancholy, sleep disturbances, irritability, and stress. These feelings and conditions of this kind can generate impacts on the caregivers' lives that negatively affect their physical, psychological, psychosocial and financial health. ${ }^{19}$

Impacts on caregivers are pointed out in international studies that highlight factors that need to be observed by health professionals: lack of information (in particular, inconsistent information about health services), inadequate professional support, ineffective communication and lack of knowledge on legal and financial issues. ${ }^{20}$

Caregiver orientation is an essential aspect to provide good clinical care for the patient with MND. Called the 'invisible patient', the caregiver who experiences the stress of the care experience often has no support for this service. ${ }^{21}$

A survey carried out in a public hospital in Ribeirão Preto (SP)/ Brazil, with 101 elderly caregivers with $\mathrm{AD}$, sought to trace care profiles associated with resilience - the ability to recover and adapt to difficult situations. The study showed that the sociodemographic, health and lifestyle habits influence the caregiver's capacity for resilience. When caregivers had knowledge about the disease and received help, they were able to perform the task of caring more effectively. According to this research, the elderly are benefited by a resilient family caregiver, who can maintain their mental and physical balance, favoring the task of caring. ${ }^{22}$

The study by Pereira ${ }^{23}$ looked for differences between two groups of informal caregivers: the primary caregivers who took on the task of caring, and that of secondary caregivers, who collaborated in the task of caring for dependent elderly people. The results (on sociodemographic and family context, pattern of care, motives of the task and satisfaction with life) showed that the family was the main provider of care for the elderly dependent. Caregivers of both groups had low levels of satisfaction with life.

A meta-analysis by Pinquart \& Sorensen ${ }^{24}$ of 84 articles on the differences between caregivers and non-caregivers (on perceived stress, depression, general subjective well-being, physical health and efficiency) $3 \%$ ) treated caregivers of the elderly with MND, with $72 \%$ of these caregivers being women. The results indicated that caregivers have higher levels of depression and stress, and lower levels of subjective well-being, physical health and efficiency compared to non-caregivers. The study also showed that caring for relatives with MND was associated with higher stress levels and a high risk of poor physical and psychological health.

The aggravation of the impacts on the care task is further accentuated by the symptoms that the elderly with MND develop, such as: irritability, agitation, anxiety, apathy, depression, sleep disorders, MND with neuropsychiatric symptoms (delirium) and preexisting diseases. If left untreated, these symptoms of the elderly 
may aggravate the overload of the caregiver to the point of developing emotional problems, such as depression. On the other hand, social and psychological support, training for care and spirituality appear as positive factors in the reduction of this overload. ${ }^{25-28}$

Thus, research shows that caring for an elderly person with MND is a complicated task, especially when there is little information and support. Therefore, it is of fundamental importance the work of health professionals who will guarantee, in the form of support, information that will have a direct impact on the life of the caregivers and the elderly with MND. ${ }^{29}$

The psychological overload of caregivers is perceived to be higher in those with better education, ${ }^{30}$ and levels of satisfaction are more related to the personal context and characteristics of the caregiver than to their gender. ${ }^{31}$

A clinical trial by Chen et al..$^{32}$ on the overload of elderly caregivers with MND, indicated the effectiveness of a psychosocial intervention, based on an investigation with two groups of caregivers (with and without intervention). From the results obtained, psychosocial support and individual education can help caregivers to adopt coping strategies that are beneficial for reducing the burden. The intervention facilitated the problem-centered strategies that enabled the caregiver to face reality, managing the difficulties and making an effort to build a more acceptable situation regarding care for the MND. However, it was observed that the intervention did not reduce negative coping strategies (avoidance, delusional thinking and self-defense).

Regarding the caregivers' confrontation with the situations generated by care, a review by Kneebone $\&$ Martin $^{33}$ which selected 12 cross-sectional and four longitudinal studies for analysis, identified which strategies for problem solving and coping styles can be advantageous for the caregivers of people with MND. Another study, by Santos et al. ${ }^{34}$ made a systematic review on theoretical and methodological models of intervention in caregivers of patients with MND and pointed out that the interventions may be psychoeducational, psychosocial and psychotherapeutic, and all have the objective of providing the caregiver strategies for coping and management of the difficulties of caring. For these authors nonpharmacological approaches have positive effects although they still require more rigorous studies.

The factors described above are important findings for the evaluation of the psychological, emotional and behavioral aspects of the caregiver. According to Achenbach, ${ }^{35}$ psychological problems are characterized by patterns of symptoms, which can be divided into two types: externalizing (behavioral) and internalizing (emotional) Outsourcing problems are expressed in relation to other people in the relationship with the outside world, such as hyperactivity, aggressiveness, and antisocial behaviors, which are usually linked to conduct disorder and oppositional defiant disorder. ${ }^{36,37}$ The internalizing problems are those that express themselves in relation to the individual; are situated in the affections and in the more intimate psychological environment, such as anxiety, depression, sadness, withdrawal, somatic complaints and fear. Internalizing problems are usually related to mood (depression) and anxiety disorders. ${ }^{36,37}$

Within the limits of the above-mentioned considerations, this study aims to verify indicators of adaptive means, emotional and behavioral problems of caregivers of the elderly with MND in a Brazilian sample.

\section{Method}

A family sample of 54 elderly caregivers, nine males and 45 females, aged 18-59 years old, living in the Baixada Santista (metropolitan region of the State of São Paulo/Brazil), were selected according to the criteria of convenience and accessibility, without characterizing a probabilistic sample, assisted by three services in the region for care for elderly people with dementia, and their families. Participants were responsible for full or partial care of the elderly for at least three days a week.

After a sociodemographic survey data (which also included verification of the degree of kinship and length of care), it was used the Adult Self-Report (ASR), an instrument of the Achenbach System of Empirically Based Assessment (ASEBA) of Achenbach \& Rerscorla38, composed of 126 items that aim to evaluate the adaptive means, in terms of total competence, activities and social competence. It also makes it possible to identify internalizing and externalizing psychological problems. The evaluation of the answers gives indicators of classification in the ranks: a) non-clinical (or normal); and b) borderline and clinical (the latter indicative of need for clinical intervention to different degrees). ${ }^{38}$ In the research were used the Scales of Adaptive Means, Internalizing Problems, Externalizing Problems, Total Problems. For scales of problems, the non-clinical range is the one with scores lower than 60; the borderline/clinical range with larger scores 60 . At scales for adaptive means, the nonclinical range is the one with scores greater than 35 and the clinical/ borderline range is the one with scores equal to or lower than 35 . There is evidence of ASR validity for the Brazilian reality. ${ }^{39}$

The participants answered the ASR individually, in the format of interview, in the dependencies of the investigated services, by means of signing the Term of Free and Informed Consent, according to ethical indications of the research with human beings.

Data analysis software ADM was used to obtain the values of $\mathrm{t}$ score of internalizing problems, externalizing problems, total problems and adaptive means. For comparisons of the means between the ASR variable (adaptive means) and the time of care was used the analysis of variance of Tukey.

\section{Results and discussion}

The majority of the sampled caregivers were women (45), aged between 19 and 59 years, mean of $45.91 \pm 10.09$ years, and men (9), the age ranged from 18 to 59 years, with a mean of $39.89 \pm 14.22$ years.

Table 1 presents the results of frequency and percentage of borderline and/or clinical and non-clinical ranges, obtained by ASR.

The data in Table 1 show that the majority of the caregivers did not perform paid activity, were daughters of the elderly, and had been in care for more than three years. Of the child caregivers of this sample, four were single children (one man and three women). Table 1 also points to a reference for good and/or ambivalent feelings (good and bad), with men reporting more ambivalent feelings and women with more good feelings, as well as indicating a condition of greater fatigue for men and women who cared for more than three years. However, most of the sample shared the care of the elderly with another person for more than three hours a day. Most of the investigated (seven men and 39 women) indicated that there had been changes in their social relations, from the care situation. 
Table I Descriptive measures (frequency and percentage) of the sociodemographic data

\begin{tabular}{|c|c|c|c|}
\hline & & Frequeny & Percentage \\
\hline \multirow{3}{*}{ Perform paid activity } & Yes & 20 & 37 \\
\hline & No & 34 & 63 \\
\hline & Children & 37 & 68,5 \\
\hline \multirow{3}{*}{ Kinship relationship with the elderly } & Spouse & 5 & 9,3 \\
\hline & Son-in-law/daughter-in-law & 6 & $\mathrm{II}, \mathrm{I}$ \\
\hline & Others & 6 & $\mathrm{II}, \mathrm{I}$ \\
\hline \multirow[t]{4}{*}{ Time (years) of care } & $<1$ year & 18 & 33,3 \\
\hline & I-3 years & 5 & 9,3 \\
\hline & $>3$ years & 31 & 57,4 \\
\hline & Good & 26 & 50 \\
\hline \multirow[t]{3}{*}{ Feelings about care / senior } & Good and bad & 16 & 30,8 \\
\hline & Bad & 10 & 19,2 \\
\hline & $\leq 3$ & 15 & 27,8 \\
\hline \multirow[t]{2}{*}{ Fatigue level } & 04-Jun & 13 & 24,1 \\
\hline & 07-Oct & 26 & 48,1 \\
\hline \multirow{3}{*}{ Shares the care } & Yes & 42 & 77,8 \\
\hline & No & 12 & 22,2 \\
\hline & $<$ I hours & 6 & 14,3 \\
\hline \multirow[t]{2}{*}{ Time that share the care (hours/day) } & I-2 hours & 6 & 14,3 \\
\hline & $>3$ hours & 30 & $7 I, 4$ \\
\hline \multirow{2}{*}{$\begin{array}{l}\text { Changes in the social relationship because of } \\
\text { the care }\end{array}$} & Yes & 47 & 87 \\
\hline & No & 7 & 13 \\
\hline
\end{tabular}

Table 2 presents the results of Adaptive Means and Psychological Problems (internalizing/emotional and externalizing/behavioral) descriptive of ASR are presented.

Table 2 Descriptive measures of Adaptive Means, Internalizing problems, Externalizing problems, Total problems, ASR, average, standard deviation, minimum and maximum, gender

\begin{tabular}{lllll}
\hline & Men & 58,33 & $1 \mathrm{I}, 86$ & $41-77$ \\
Internalizing & Women & 60,04 & 8,91 & $40-8 \mathrm{I}$ \\
problems & Total & 59,76 & 9,36 & $40-8 \mathrm{I}$ \\
& Men & 49,33 & 12,32 & $32-70$ \\
Externalizing & Women & 51,96 & 9,31 & $32-72$ \\
problems & Total & 51,52 & 9,79 & $32-72$ \\
& Men & 52,78 & 12,54 & $34-72$ \\
Total & Women & 55,53 & 8,27 & $40-69$ \\
problems & Total & 55,07 & 9,03 & $34-72$ \\
& Men & 48,56 & 7,86 & $30-55$ \\
& Women & 45,22 & 9,75 & $34-60$ \\
Adaptative & Total & 45,78 & 9,47 & $24-60$ \\
means & & & & \\
\hline
\end{tabular}

According to Table 2, internalizing (emotional) problems were indicated in borderline/clinical ranges, those indicative of clinical concerns were more present in women.
Figure 1 presents the distribution of adaptive means scores according to time (years) of care is shown

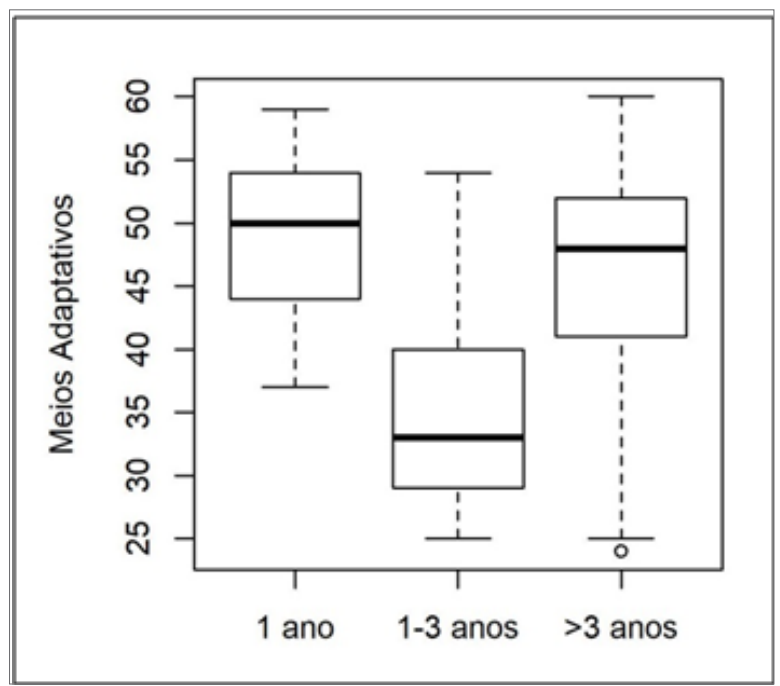

Figure I Distribution of the variable adaptive means according to time (years) of care.

According to Figure 1, regarding the time of care, only internalizing problems in borderline/clinical range were pointed out, for participants with up to one year of care. From the data presented in figure 1 only for the variable care time $(<1$ year, 1-3 years, $>3$ years $)$, in relation to the adaptive means, a statistically significant difference was found $(p=0.014)$. The results of Tukey's analysis of variance 
allow us to say that those who cared for the elderly for up to one year $(<1$ year) had the mean of adaptive means higher than those who took one to three years (1-3 years).

Most of the caregivers investigated in this study were female (45 women). This data, from the prevalence of women as caregivers, is also found in other investigations on the subject. ${ }^{12,19,40,41}$ In the sample studied here, the majority of caregivers were daughters of the elderly and with care for more than three years. Of the child caregivers found in this study, four were single children (one man and three women). The increase of single-child families represents a new paradigm, and will be a challenge for the next generations in the middle of the $21 \mathrm{st}$ century in Brazil and in much of the world, this aspect raises questions about how society can deal with the elderly population without help of family caregivers. ${ }^{42}$

The mean age of the investigators was 38.89 years for men and 45.91 years for women, indicating that caregivers were mostly middle aged, which according to Erikson is the time of the person to be productive and to be fit for the activities of caring. ${ }^{43,44}$ This stage is seen as the one in which adults learn to counterbalance love, autonomy and obligations with parents in a double-track relationship. ${ }^{45}$

The ASR results for behavioral (externalizing) problems showed indicative of borderline/clinical ranges. However, regarding the emotional (internalizing) problems, the borderline/clinical range (indicative of the need for intervention) was more present in women. According to the time of care, the caregivers showed clinical/ borderline ranges in the first year of care. This data suggests that in the initial stage of the care process, the family caregivers of this study were more vulnerable to this situation, without having developed adequate coping strategies and adaptation to the care experiences. The results still pertinent to these emotional problems tended to fall in those family caregivers with a period of care of one to three years (possible adaptation stage), increasing in the caregivers with more than three years in the task (possible stage of exhaustion). ${ }^{38}$

On the other hand, data from the ASR Adaptive Means Scale related to the time of care indicated a situation in which the caregiver of the elderly one year old presented averages of ad- tractive resources greater than those who cared for the relative of one to three years. These results seem to indicate that the losses related to social skills and friendships have been installed as the time of care increased, contributing to a situation of social isolation. According to Achenbach \& Rescorla, ${ }^{38}$ ASR's adaptive media data cover relationships with friends, education, work, the family and the relationship with the spouse or partner, and make it possible to outline the adaptive functioning profile as well as verify indicatives of disorders.

These adaptive resources can be favored by providing and increasing information on the MND, for example, caregivers can develop new coping strategies for anxiety and stress, for gradual and positive adaptation to the new daily life imposed by care. ${ }^{29,34,41,46}$ The preparation of caregivers to perform the task of care may be an ally in the face of the difficulties that caring represents.

It should be added that an element to be considered in the dynamics of family care is the preparation of the elderly for important decisions about their possible future care, including the possibility of expressing their preferences regarding the appointment of persons responsible for them, when care performed within the family. This is one more condition to be reflected in the field of broad and complex interactions between the elderly with MND and their family caregiver - a field still to $\mathrm{be}^{20,47}$ to support future interventions that favor human development in all stages (and tasks) of life.

It should be emphasized that there may be increased anxiety among caregivers in cases of merely informative programs that do not offer adequate support, anticipating bereavement due to greater knowledge about the disease. ${ }^{48}$ However, interventions can improve psychological effects through the reduction of negative feelings and non-adaptive thoughts, for an adequate coping of the caregivers. ${ }^{49}$

\section{Final considerations}

The results indicated the presence of emotional impacts, vulnerability and stress from the caring activity, in caregivers of the elderly with MND. Within the limits of this study, it is possible to suggest some indicators for a family care technology for the elderly, including: offering psychological guidance for family caregivers; clarifications on economic and legal aspects that involve the issues of the life of the elderly and family; individual and group psychotherapeutic support; creation/extension of psychosocial support networks (such as day care facilities for the elderly); and expansion and diversification of the public services network to meet the needs of the elderly and their family caregivers.

\section{Acknowledgements}

None.

\section{Conflict of interest}

The authors declare no conflict of interest.

\section{References}

1. Eizirik CL. O ciclo da vida humana: uma perspectiva psicodinâmica, Porto Alegre: Artmed; 2001.

2. Ministério da saúde. Envelhecimento e saúde da pessoa idosa. Autor, Brasilia, Brazil. 2007.

3. Fartel JM, Filho W. Epidemiologia e fisiologia do envelhecimento. In: Filho WJ. Demências - Enfoque Multidisciplinar: das bases fisiopatológicas ao diagnóstico e tratamento. São Paulo, Atheneu; 2011.

4. Freitas EV. Tratado de Geriatria e Gerontologia. $3^{\text {rd }}$ ed. Brazil, Rio de Janeiro, Guanabara Koogan; 2010.

5. http://www.who.int/whr/2008/whr08_en.pdf

6. Pivetta M, Zorzetto R. Os mecanismos do envelhecimento. Pesquisa Fapesp. 2017;254:18-25.

7. http://www.ibge.gov.br/apps/populacao/projecao/

8. Sancho LG. Atenção à saúde na síndrome demencial: qual será o impacto econômico dessa atenção no Brasil?. Saúde em Debate. 2015;39(105):551-560.

9. American psychiatric association (APA). Manual diagnóstico e estatistico de transtornos mentais. 5th edition, Porto Alegre, Artmed; 2015.

10. Guia. Cuidados com a saúde: 301 dicas para evitar Alzheimer. 5th ed. On Line Editora, Brazil, São Paulo; 2016. 
11. Machado JC. Doença de Alzheimer. In: Freitas. et al. Tratado de Geriatria e Gerontologia. 3rd ed. Rio de Janeiro, Guanabara Koogan; 2011.

12. Rossi VE. Perfil dos cuidadores de idosos com doença de Alzheimer de uma cidade do interior de Minas Gerais. Revista Ciência Et Praxis. 2017;8(16)27-32.

13. www.caregiver.org/caregiver-statistics-demographics

14. Organização Mundial de Saúde (OMS).CIF: Classificação Internacional de Funcionalidade, Incapacidade e Saúde. 2004.

15. Duarte YAO, D'elboux MJ, Berzins MV. Cuidadores de Idosos. In: Freitas EV. Tradado de Geriatria e Gerontologia. $4^{\text {th }}$ ed, Rio de Janeiro, Guanabara Koogan; 2016.

16. https://www12.senado.leg.br/noticias/materias/2017/09/06/casdiscute-regulamentacao-da-profissao-de-cuidador

17. Paulino FG.O cuidador familiar da pessoa com demência: repercussões e intervenções. In: Filho W. et al. Demências - Enfoque Multidisciplinar: das bases fisiopatológicas ao diagnóstico e tratamento, São Paulo, Atheneu; 2011

18. Gratão ACM, Luana FST, Leandro $\mathrm{CF}$, et al. Dependência funcional de idosos e a sobrecarga do cuidador. Revista da Escola de Enfermagem da USP. 2013;47 (1):137-144.

19. VAN Durme T. Tools for measuring the impact of informal caregiving of the elderly: A literature review. International Journal of Nursing Studies. 2012;49(4):490-504.

20. Silva AL. Teixeira HJ, Teixeira MJ, et al. The needs of informal caregivers of elderly people living at home: an integrative review. Scandinavian Journal of Caring Sciences. 2013;27(4)792-803.

21. Sanders AM. Caregiver stress and the patient with dementia Continuum. 2016;22(2):619-625.

22. Gaioli CCLO, Furegato ARF, Santos JLF. Perfil de cuidadores de idosos com doença de alzheimer associado à resiliência. Texto \& Contexto Enfermagem. 2012; 21(1):150-157.

23. Pereira ASCA. Family caregivers and dependent elderly: profile, motives and satisfaction with life. Dissertation. Portugal, University from Aveiro; 2008.

24. Pinquart M, Sorensen S. Differences between caregivers and noncaregivers in psychological health and physical health: a meta-analysis. Psychology and Aging. 2003;18(2):250-267.

25. Huang SS, Lee MC, Liao YC, et al. Caregiver burden associated with behavioral and psychological symptoms of dementia (BPSD) in Taiwanese elderly. Archives of Gerontology and Geriatrics. 2012;55(1):55-59.

26. Pereira LSM, Soares SM. Factors influencing the quality of life of family caregivers of the elderly with dementia. Ciênc. saúde coletiva . 2015;20(12):3839-3851.

27. Silva FAR. Sobrecarga de cuidadores familiares e capacidade funcional de pacientes com Acidente Vascular Cerebral. Dissertation. Universidade Federal de Goiás, Goiânia; 2017.
28. Terum MT, John RA, Arvid R, et al. The relationship of specific items on the Neuropsychiatric Inventory to caregiver burden in dementia: a systematic review. International Journal of Geriatric Psychiatry. 2017;32(7):703-717.

29. Brun AKR. Programa para cuidadores de idosos com demência: relato de experiência. Revista Brasileira de Enfermagem. 2013;66(4)619-624.

30. Rosdinom R. Zarina MZN, Zanariah MS, et al. Behavioural and psychological symptoms of dementia, cognitive impairment and caregiver burden in patients with dementia. Preventive Medicine. 2013;57:67-69.

31. Del PCR. et al. Gender differences regarding informal caregivers of older people. Journal of Nursing Scholarship. 2012;44(4): 349-357.

32. Chen HM, Huang MF, Yeh YC, et al. Effectiveness of coping strategies intervention on caregiver burden among caregivers of elderly patients with dementia. Psychogeriatrics. 2015;15(1):20 25 .

33. Kneebone II, Martin PR. Coping and caregivers of people with dementia. British Journal of Health Psychology. 2003;8(pt 1):117 .

34. Santos RL. Sousa MF, Dourad M, et al. Intervenções de grupo para sobrecarga de cuidadores de pacientes com demência: uma revisão sistemática. Rev Psiquiatria clínica. 2011;38(4)161-167.

35. Achenbach TM. Manual for the Child Behavior Checklist/4-18 e 1991 profile. Burlington: University of Vermont; 1991.

36. Achenbach T, Howell C. Are American children's problems getting worse? A 13-year comparison. Journal of American Academy on Child and Adolescent Psychiatry. 1993;32(6):11451154.

37. American Psychiatric Association (APA) Manual diagnóstico e estatístico de transtornos mentais. 4th edition. Porto Alegre, Artmed; 2002.

38. Achenbach TM, Rescorla LA. Mental Health practitioners' guide for the achenbach system of empirically based assessment (ASEBA) 7th ed. University of Vermont, Burlington; 2010.

39. LucenaSP, Moraes JFD, Oliveira MS. Analysis of the factor structure of the syndromic scales of the ASR (Adult Self-report). Interamerican J Psychol. 2014;48(2):252-262.

40. Novelli MMPC, Nitrini R, Caramelli P. Caregivers of elderlies with dementia: their social and demographic profile and daily impact. Rev Ter Ocup. 2010;21(2):139-147.

41. Seima M D, Lenardt MHA. Sobrecarga do cuidador familiar de idoso com Alzheimer. Textos \& Contextos. 2011;10(2):388-1398.

42. Camarano AA. Politica de Cuidados para a População Idosa/ Necessidades, Contradições e Resistências. In Tratado de Geriatria e Gerontologia. 4th ed. Rio de Janeiro, Brazil, Guanabara Koogan; 2016

43. Abreu MC. Velhice: uma nova paisagem. São Paulo, Ágora; 2017. 
44. Lima PMR, Coelho VLD, Günter IA. Envolvimento vital: um desafio da velhice. Geriatr Gerontol Aging. 2011;5(4):261-268.

45. Papalia DE. Desenvolvimento Humano. Trad. Daniel Bueno. $8^{\text {th }}$ ed. Porto Alegre, Brazil. Artmed; 2006.

46. Thompson ML. Information-seeking coping and anxiety in school-age children anticipating surgery. Children's Health Care. 1994; 23(2):87-97.
47. Burlá C, Ana AC, Solange K, et al. Panorama prospectivo das demências no Brasil: um enfoque demográfico. Ciência \& Saúde Coletiva. 2013;18(10):2949-2956.

48. Aakhus E. Knut E, Tom A. Single session educational programme for caregivers of psychogeriatric in-patients - results from a randomised controlled pilot study. International Journal of Geriatric Psychiatry. 2009;24(3):269-274.

49. http://www.politize.com.br/politicas-publicas-o-que-sao/ 